\title{
PERCEPTIONS ON PLAGIARISM AND THE IMPLICATIONS FOR TEACHING AND LEARNING STRATEGIES AT AN EMI UNIVERSITY IN INDONESIA
}

\author{
Risa Fitria \\ President University \\ Email: fitria.risa@president.ac.id
}

\begin{abstract}
This study tries to answer two questions, namely 1) What do the lecturers and the students perceive about the practice of plagiarism in L2 writing? 2) What strategies did the lecturers and the students apply to writing L2 to avoid plagiarism? This study aimed at investigating the views of lecturers and students on plagiarism and its implications for teaching and learning at one of the EMI universities in Indonesia. The findings showed that both lecturers and students had negative views towards plagiarism. However, even though plagiarism was considered as an unacceptable behavior, the students would be likely to commit plagiarism under certain circumstances. Back translation was also found to be the most common strategy that the students used to avoid plagiarism. The study finally recommended higher education institutions to equip students with necessary language and writing skills needed in academic settings as early as possible in order for them to avoid plagiarism.
\end{abstract}

Keywords: Perceptions; Plagiarism; Strategies.

\section{INTRODUCTION}

The cases of plagiarism that occurred from the level of lecturers to students in Indonesia are increasing. The wrongdoing acts have been ranging from buying and selling diplomas to plagiarizing the work of others. The phenomena are surely worrying amidst the Indonesian government's efforts to increase the number of international publications in Southeast Asia. Currently, Indonesia has managed to get the 2nd position in ASEAN in terms of quantity of international scientific publications, ahead of Singapore that is ranked the 3rd (Seftiawan, 2018). Therefore, the government is strongly committed to improving the quality of scientific publications in Indonesia and preventing plagiarism at all levels, particularly in higher education institutions. To prevent plagiarism, the government issued the Regulation of the Minister of National Education of the Republic of Indonesia Number 17 of 2010

\section{Open Access}

Creation is distributed under the Creative Commons License Attribution-Share Alike 4.0 International

Published in http://ejournal.umpri.ac.id/index.php/smart/index 
concerning Prevention and Management of Plagiarism in Higher Education. The law explains what constitutes plagiarism and sanctions given to the perpetrator. In Indonesia, the emergence of English as a Medium of Instruction (EMI) universities, such as the President University, which requires communication in English, requires students to be able to write in English (L2 writing). This makes students who speak Indonesian (L1) struggle to not only understand how to quote but also include the process of transferring ideas and languages as well as understanding different academic cultures. The author as a lecturer in Academic Writing courses realizes that it is not easy for some students to write in foreign languages, especially for those with low English proficiency. For these students, they do not yet have enough academic English vocabulary to make a text as private property without mixing up words or phrases from the text with other texts that might be considered plagiarism by some teachers. In short, plagiarism in writing scientific papers in English (L2) cannot be simplified only to academic violations. Howard (1995) says that students need a text as a model (imitation and appropriation) when writing that can help L2 writers develop their L2 writing skills. Howard (1999) introduces a patchwriting strategy that is often used by novice writers to imitate the language of a text. However, this will create misunderstandings in the teaching and learning process. Therefore, they will continue to take actions that are considered as acts of plagiarism. Differences in perceptions between teachers and students will create misunderstandings that will further enhance the act of plagiarism.

According to Hacker (1991), plagiarism occurs when someone borrows someone else's idea and does not recognize the original source or even though the original source was acknowledged but the text is too similar to the original source. In a similar vein, Pecorari (2013), through surveys at various universities in America, found consistency in the formulation of the meaning of plagiarism, namely as taking material either intentionally or unintentionally from several sources without acknowledging them. In Indonesia, the definition is provided in the Regulation on Prevention and Mitigation of Plagiarism in Higher Education issued by the Ministry of National Education Number 17. Akbar and Picard (2019) have provided the English translation ofplagiarism in the Indonesia's Regulation, that is, "Plagiarism refers to intentional or unintentional acts to gain or to endeavour credits or marks from a scientific work by quoting others' work, either partially or completely, claimed as one's work without accrediting the source correctly and appropriately". From these definitions it can be concluded that acts of plagiarism in the academic world are categorized as academic crimes and / or copyright violations. However, research in L2 writing said that when talking about plagiarism in L2 writing (in this case English), the discussion will be far 
Risa.....

more complex since many factors such as students' language barriers and educational backgroundsplay an important role in the process of writing using English.

Moreover, several studies conducted in Indonesia found that the unfamiliarity of writing and the absence of sanctions made them prone to plagiarism. Adiningrum and Kutieleh (2015) examined Indonesian students who were studying at several universities in Australia. Through a series of group discussions, some participants stated that their academic experience in Indonesia was not too concerned with the quality of writing or even paying attention to plagiarism. They also said that when writing scientific papers they were taught the terms of the quotation but there were no penalties imposed if they violated so plagiarism was more likely to occur. Agustina and Raharjo (2017) also found the same thing in their research. The study participants admitted that they were likely to commit plagiarism because of the absence of sanctions. However, they admitted that plagiarism is a wrong action based on religious teachings. The participants who were students at a university in Indonesia recognized that plagiarism is taking someone's property, and it is prohibited by religion.

In Agustina and Raharjo's (2017) study, students are forced to do plagiarism because of the many tasks that must be done and they do not have time to understand every word in the book. They also have a strong desire to get good grades for every task they do. Keck (2014) argues that inexperienced writers tend to copy writing in original sources. Pecorari (2013) revealed a number of strategies used by novice writers, one of which was patchwriting. Howard (1999) introduces the term patchwriting as a process of rewriting a text source by substituting the words, altering the grammar, and/or entering synonyms. According to Pecorari (2013) patchwriting should not be included as a category of plagiarism because patchwriting can help novice writers especially those who are not foreign speakers (L2) to develop their writing. This opinion is supported by research conducted by Villalva (2006) on two L2 students in America. One participant used patchwriting extensively by combining the words contained in the original text and the results of the student's original paraphrase. But surprisingly, the final result of the student essay can produce original writing without using too much patchwriting. In this case, the patchwriting strategy shows the learning process that is still ongoing. According to Pecorari (2013), the sanction of plagiarism in cases like this can reduce a student's opportunity to develop his writing skills because at this stage new beginners present in the academic community which makes them not sure of the writer's voice they have so they still need a patchwriting strategy. However, things this is still a debate among researchers and practitioners. 
Because of the complexity of the problems surrounding plagiarism, students' and lecturers' perspectives on plagiarism are very important because their understandings of plagiarism will affect their actions when they do or assign assignments using English. The purpose of this mixed-methods research is to evaluate the perceptions of lecturers and students regarding plagiarism carried out by students. The emergence of the EMI (English as a Medium of Instruction) university in Indonesia has made the plagiarism policy need to be reviewed. In a university that requires communication in a foreign language, namely English, the prevention and discussion of plagiarism is far more complex. The necessity of writing in English (L2 writing) makes students who speak Indonesian (L1) must struggle to not only understand how to quote but also include the process of transferring ideas and languages. This study tries to answer two questions, namely 1) What do the lecturers and the students perceive about the practice of plagiarism in L2 writing? 2) What strategies did the lecturers and the students apply to writing L2 to avoid plagiarism? This study aims to determine the views and understanding of lecturers and students on plagiarism and its implications for teaching and learning at one of EMI Universities in Indonesia.

\section{RESEARCH METHODS}

This study attempted to investigate the students' and lecturers' perspectives on plagiarism. The study was inspired by Power's (2009) study that utilised the grounded theory in running and analysing the data. Our study had a similarity to what we tried to understand university lecturers' and students' perspectives on plagiarism in higher education. Since this study attempted to find out the pattern of the participants' answers, thus, the grounded theory was deployed so that the data would be "discovered, developed, and provisionally verified through systematic data collection and analysis. Therefore, data collection, analysis and theory stand in reciprocal relationship with one another" (Strauss \& Corbin, 1998, p. 23).

The study used two methods, questionnaire to obtain the participants' perceptions on plagiarism and interview. First, the questionnaire for the lecturers and students were developed based on Wilhoit's (2005) article and Cengage's (2015)survey modified by the researcher using a literature review and adjusted to the context of the research location. Then, the questionnaire was distributed to several participants as a pilot project on Google. The research revised the questionnaire based on the participants' inputs. After the revision, the final questionnaire was distributed online to all lecturers and students from batch 2016, 2017, and 2018. The reason the study involved only these batches because they have been exposed to the experience of academic writing such as writing essays or thesis and, thus, prone to 
Risa.....

committing plagiarism. The study also used a semi-structured interview because it was designed to explore the participants' experiences related to their plagiarism perspectives and how their experiences affected their pedagogical practices and learning strategies to avoid plagiarism. A semi-structured interview has several benefits since it can guide the research by having a list of questions so the discussion can be efficiently conducted (Heigham \& Crocker, 2009). At the same time, the questions can be slightly or wholly modified or adapted depending on the situation when the interview is conducted. In addition, this study selected five lecturers and five students to be interviewed by using purposive sampling as it aimed at obtaining data with specific goals and uses (Sugiyono, 2016).

\section{FINDINGS AND DISCUSSION}

\section{Survey}

Based on the descriptive statistics gathered from the questionnaire, the number of participants involved in this study was 348 students and 39 lecturers.

Table 1. Demographics of Student Participants $(\mathrm{N}=348)$

\begin{tabular}{llll}
\hline & Characteristics & Frequency & Percentage \\
\hline Gender & Male & 128 & $36.8 \%$ \\
& Female & 220 & $63.2 \%$ \\
\multirow{3}{*}{ Year } & 2016 & & \\
& 2017 & 51 & $14.7 \%$ \\
& 2018 & 139 & $39.9 \%$ \\
\multirow{5}{*}{ Faculty } & & 158 & $45.4 \%$ \\
& Business & & \\
& Engineering & 197 & $56.6 \%$ \\
& Humanities & 46 & $13.2 \%$ \\
& Computer Science & 69 & $19.8 \%$ \\
& & 36 & $10.4 \%$ \\
\hline
\end{tabular}

Table 1 shows that students who were involved in this study consists of 128 male $(36.8 \%)$ and 220 female $(63.2 \%)$. It can be seen that the number of female students participating in this study was higher than their counterparts. The participants were intheir second, third and fourth year of study which consisted of four faculties, namely, Business (56,6\%), Humanities (19.8\%), Engineering, (13.25) and Computer Science (10.4\%). 
Table 2. Demographics of Lecturer Participants $(\mathrm{N}=39)$

\begin{tabular}{llll}
\hline & Characteristics & Frequency & Percentage \\
\hline Gender & Male & 27 & $69.2 \%$ \\
& Female & 12 & $30.8 \%$ \\
Years of & & & \\
teaching & $1-2$ years & 10 & $25.6 \%$ \\
& $3-5$ years & 14 & $35.9 \%$ \\
& $>5$ years & 15 & $38.5 \%$ \\
Faculty & Business & 19 & $41.1 \%$ \\
& Engineering & 8 & $20.5 \%$ \\
& Humanities & 11 & $28.3 \%$ \\
& Computer Science & 1 & $2.6 \%$ \\
\hline
\end{tabular}

Meanwhile, Table 2 illustrates that the number of lecturers participating in this study was 39. The table demonstrates that more than half of population was male lecturers $(69.2 \%)$ while female lecturers were $30.8 \%$ of the population. Based on their teaching experience, half of the participants had the experience less than five years of teaching in English. The respondents taking part in the study were mainly from the Faculty of Business (19 people), followed by Faculty of Humanities (11 people), Engineering (8 people), and Computer Science (1 person).

\section{Data Analysis}

After receiving the questionnaire, the data were analyzed by choosing the words and coded them according to their similarities. The first question in the questionnaire was asking the respondents (both students and lecturers)to provide a definition of plagiarism by using their own words. The data analysis was presented in the findings and discussion session. The second question in the survey asked the students the strategies they used to minimize plagiarism in their L2 writing. In this question, the respondents could choose more than one answers. The strategies were adapted from Wilhoit's (1994) strategies to avoid students from committing plagiarism. However, the first option, deploying back-translation method by using language translation software (e.g Google Translate), was added by the researcher because of her experience in the classroom where many of her students usedthis method in their writings. 


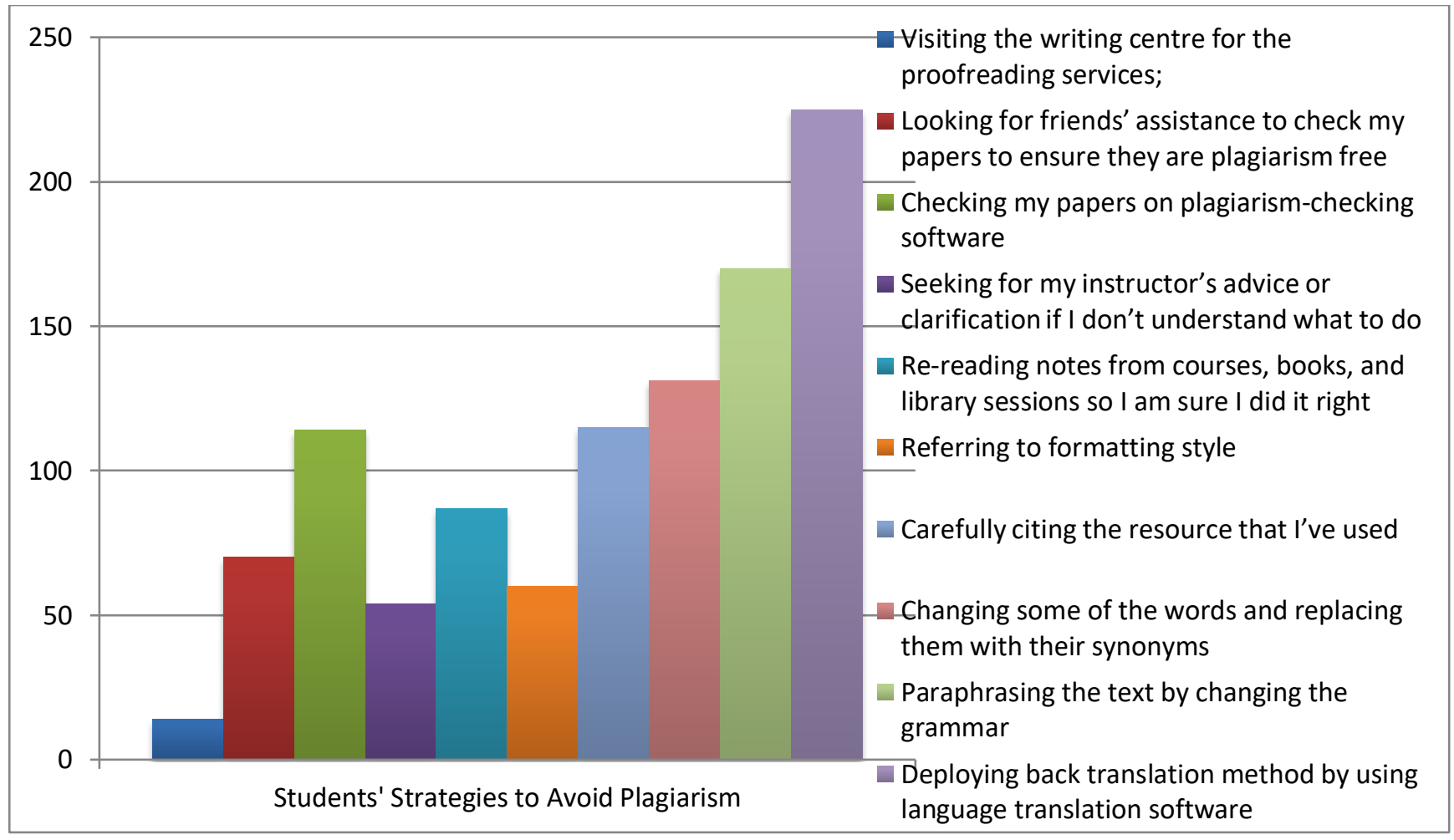

Figure 1 Strategies Used by Students to Avoid Plagiarism

Based on Figure 1, it can be seen that most of the students (225) used back translation method to help them write in L2 writing. Back translation is a method in which students translate English text into another language (in this case into Indonesian) and retranslate the Indonesian version into English with the assistance of Google Translate. The second strategies that mostly the students used was paraphrasing the text by changing grammar and followed by replacing words with their synonyms. The other prominent strategy was the students used software to check the percentage of plagiarism contained in their L2 writing.

Figure 2 illustrates how the lecturers responded to the phenomenon of plagiarism occurred among students. There were 27 lecturers choosing defining and discussing plagiarism with their students as their first strategy. To deter plagiarism, the second option was reviewing the conventions of quoting and documenting materials. Some of the lecturers (12) used different methods according to the mistakes the students made or gave the students lower the score. 


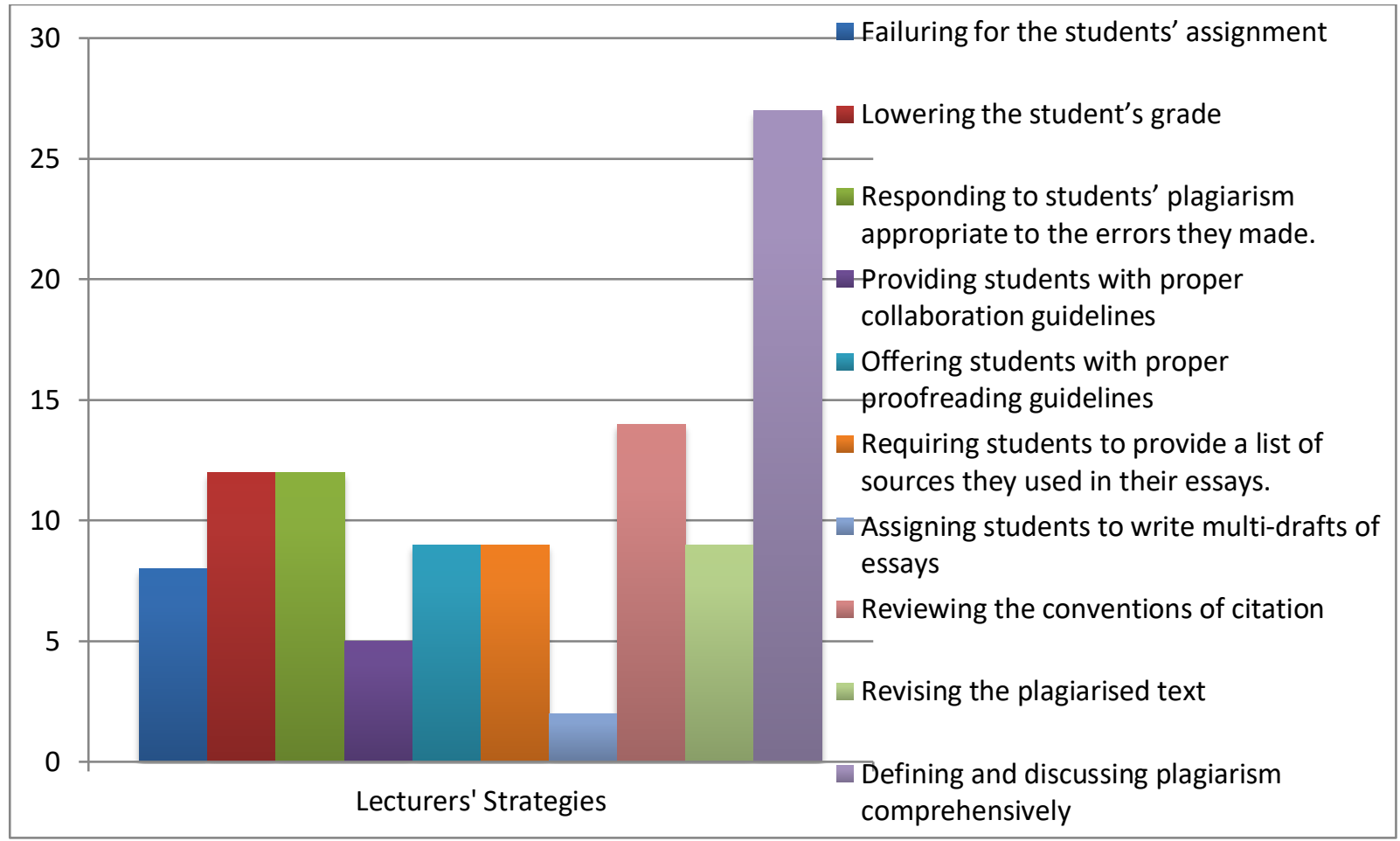

Figure 2 Strategies Used by Lecturers to Deter Plagiarism

\section{Interview}

The study involved 10 interviewees consisting of 5 lecturers and 5 students coming from across disciplines. It used a semi-structured interview lasting between $30-60$ minutes and the interviews were manually transcribed afterwards. Ten participants consist of 1 male and 4 female lecturers, and 2 male and 3 female students (see Table 1). Three of the lecturers were English instructors and 7 of them were faculty members of accounting, actuarial science, management, law, and communication. Meanwhile, 3 students were from accounting, 1 from business administration, and 1 from teacher's education. All of the participants interviewed were given aliases to keep their confidentiality.

Table 3. Interviewed Participants $(\mathbf{N}=10)$

\begin{tabular}{llllll}
\hline \multicolumn{2}{c}{ Lecturer } & & & Student \\
\hline Name & Gender & Major & Name & Gender & Major \\
Anita & Female & Education & Anto & Male & Accounting \\
Hari & Male & Communication & Romi & Male & Accounting \\
Denise & Female & Education & Esa & Female & Business Administration \\
Kia & Female & Accounting & Cika & Female & Accounting \\
Gloria & Female & Education & Josephine & Female & Education \\
\hline
\end{tabular}

\section{Discussion}

\section{The Lecturers' and Students' Perceptionson the Practice of Plagiarism in L2 writingQuestionnaire}

The study aimed at investigating the perceptions of students and lecturers about plagiarism in students' L2 written assessments. In their study, Gullifer and Tyson (2013) state 
that it is important to understand about one's perspective on plagiarism as it canaffect one's behaviour towards the issue. Therefore, we asked the participants to define plagiarism in their own words to comprehend their understandings towards plagiarism. After receiving responses, we compared the definitions given by the respondents with the definitions available in the literature. There were four definitions of plagiarism that we referred to, namely:

1. "Two different acts are considered plagiarism: (1) borrowing someone's ideas, information, or language without documenting the source and (2) documenting the source but paraphrasing the source's language too closely, without using quotation marks to indicate that words and phrases have been borrowed (Hacker's, 1991, p.507)";

2. "(1) material that has been (2) taken from (3) some source by someone,(5) without acknowledgment and (6) with/without intention to deceive (Pecorari, 2001);

3. Plagiarism is the act, "From simple errors in citation to patchwriting and to downloading or purchasing whole essay (Shi, 2006, p. 264);

4. The Government Regulation Number 17 of 2010 concerning Prevention and Management of Plagiarism in Higher Educationin which the English version was closely translated by Akbar and Picard (2019) "Plagiarism refers to intentional or unintentional acts to gain or to endeavour credits or marks from a scientific work by quoting others' work, either partially or completely, claimed as one's work without accrediting the source correctly and appropriately" (p. 10).

Based on the above definitions, there are four elements of plagiarism emerged as follows;

1. Forms of plagiarism

2. Things that constitute plagiarism

3. Reasons on plagiarism

4. The consequences that follow

After finding the 4 elements of plagiarism from the definitions and matching them with the answers of the participants, the following were the results of the data analysis.

The first element is forms of plagiarism. Students frequently mentioned copying, taking, cheating, copying, following, copy-pasting, copying ideas, works, reviews, creations, sources, sentences of others, other experts, writers, theorists. In overall, the respondents understood without a formal agreement of the forms of plagiarism. Meanwhile, the lecturers stated the terms such as copying, using other people's opinions, claiming other works, copy-pasting, imitating, quoting, adopting thoughts and ideas of others, and cheating. Generally, the respondents understood without a formal agreement of the specific forms of plagiarism. 
The second element is things that constitute plagiarism. According to the students, plagiarism is carried out without permission from the owner or done without mentioning the name of the owner of the work / sources, performed as it is without changes (without editing), without Meanwhile, lecturers believed that students committed plagiarism if they claimed sources without paraphrasing, or without mentioning the source, without adding references, without being changed at all, and also claiming as their work.

The third element is the reasons on plagiarism behaviors: There were only two students who were able to see the causality of plagiarism and one's behavior. They said plagiarism occurred due to lack of creativity and/or intentional factors. On the other hand, one lecturer stated the cause of plagiarism was because students were exposed to the ease of technology.

The fourth element is the consequences. Students believed that plagiarism is a form of crime, similar to theft, a form of copyright infringement, a fraud leading to stealing of work of others, illegal, a form of dishonesty, a form of arbitrariness, a form of falsehood that is detrimental to the owner of the work. Meanwhile, the lecturers were aware that plagiarism is not only a common violation but also a form of behavior that violates the law, and the perpetrators can be punished according to the law. Only a small proportion of respondents were aware that there are laws that can ensnare perpetrators of plagiarism even though no one explicitly mentioned what kind of law it is. Only four respondents gave consequences from plagiarism behavior, namely; plagiarism is a form of theft of intellectual ideas, violations of academics, and forms of cheating. Only a small proportion of respondents stated that plagiarism is a form of behavior that leads to ethical violations.

Basically, based on the definition given by respondents, it can be concluded that all respondents actually understood what plagiarism is. From this condition we can examine the attitude of the participants towards plagiarism and hopefully by understanding their attitude we can discover why plagiarism still occurs among students (behavior). Attitude is defined as "a mental and neural state of readiness, organized through experience, exerting a directive or dynamic influence upon an individual's response to all objects and situations with which it is related" (Allport, 1935, p. 810). To put it simply, attitude is a person's point of view towards someone or something around him based on his experience or emotions towards someone or something. To analyze attitude, there are three components known as "ABC models" proposed by Ostrom (1969) in the field of social psychology. The three components of attitudes are 1) affective component leads to feelings felt by individuals about the object being addressed, 2) behavioural (conative) component leads to behavioral tendencies if the 
attitude object appears, and 3) cognitivecomponent is related to thoughts, ideas, and something that is considered true by individuals.

Based on the ABC model, the findings led to an understanding that all of the lecturers perceivedplagiarism as wrong, unworthy, and problematic behaviors in academic ethics. All answers led to disagreement or dislike of plagiarism behaviors. Therefore, it can be concluded that the attitude of the lecturers towards plagiarism was negative. On the other hand, based on the statements and answers of the students, it can be seen through cognitive component that all students knew and understood the meaning of plagiarism, and were aware that plagiarism was wrong and had to be avoided. All of them had the same feelings that plagiarism was something that was not liked by the majority of respondents. However, based on the behavioral component, most of the respondents responded that they would or had committed plagiarism. Based on the three determinants, it can be concluded that the attitude of all student respondents towards plagiarism was negative, but in certain contexts and for certain interests, students would still carry out plagiarism behaviors. The findings endorse the Theory of Planned Behaviour proposed by Ajzen (1991) that explain that perception does not always relate to behavior. So, in this study, students basically disagreed on plagiarism behaviors. But because they see the punishments are too lenient, they tend to plagiarize. The students might see that the plagiarism perpetrators were able to get away from their wrongdoing or their peers who committed plagiarism always got good grades.

\section{Interview}

The results of the lecturer and student interviews on their views on plagiarism can be concluded that morality issues are a major theme that concerns lecturers. The results of interviews with the lecturers demonstrated that they tended to see plagiarism as a wrongdoing and stealing of other people's ideas. Ms. Anita mentioned that doing plagiarism "What comes in my mind [related to plagiarism] is dishonesty. When we mention plagiarism, it is a serious matter, it's like violating academic integrity." Plagiarism is a wrongdoing because it is “taking one's rights" (Ms. Kia) and "stealing people's ideas" if someone took sources without acknowledging the owners (Ms. Denise). Mr. Hari further argued that higher education was not only a place to transfer knowledge to students but also a mecca to teach students about morals and ethics so that the avoidance of plagiarism became part of themselves who were part of the academic world.

On the other hand the group of students interviewed also had the same perception as their lecturer. Romi argued that taking people's words to write in their assignments is an act 
of plagiarism. Anto had the same perception but he added that plagiarism "it's not only a matter of copying and pasting but it is also taking someone's ideas." There were interesting things from the results of interviews with these students. One respondent mentioned that the participant did not have the desire to do plagiarism if he had time to do the assignment. Yet, he sometimes had to do it by copying and pasting the material because had also have other waiting.

"In the beginning, I was still excited [to do the assignment]. But sometimes, [while doing the assignment, new assignments have been given. So, be it, as long as I could finish the first one. So, I would do the copy and paste thing."

And when asked whether they were not afraid of being caught doing plagiarism, Esa replied that it would depend on whether the lecturers enforced the plagiarism policy in their classroom. Power (2009) in her study revealed the same resultsfrom her participants mentioning heaps of assignments and no time to complete them have become ones of students' reasons for doing plagiarism.

\section{The Implications in the Classroom: Lecturers' and Students' Strategies to Avoid Plagiarism}

\section{Questionnaire}

The next question on the questionnaire was the strategies that the lecturers used to deter plagiarism in their classroom. In this question, the lecturers were allowed to provide more than one answers with the assumption that the respondents could have used more than one strategy in preventing plagiarism. The results showed thatthe first strategy that most of the lecturers (27) chose was explaining and having discussions on plagiarism with the students. The second mostly used strategy the lecturers (14) used was teaching the students the rules of citation and material documentation. The third strategy was lowering the grade and providing responses according to mistakes made by students.

Meanwhile, the students were given the same question but with different options. The students' answers demonstrated that they utilized back translation with the assistance of language translation website. That was the first strategy that more than $60 \%$ of the students used in order to avoid plagiarism. The next strategies werealtering the texts by making grammatical change (170) and/or changing words and replacing them with their synonyms (131).

\section{Interview}

In the interview, the researcher asked further about the strategies that the lecturers and students used to overcome plagiarism in the students' writing using English. There were three 
big themes emerged, namely 1) lecturers' strategies to prevent plagiarism, 2) back translation in students' writings, and 3) students' and lecturers' recommendations.

\section{Lecturers' Strategies to Deter Plagiarism}

The results in the interview confirmed the findings in the questionnaire that the lecturers chose to teach the students how to provide citations, summarize and paraphrase texts. Three of the participants mentioned that in the beginning they would inform the students the conventions of quoting and how to avoid copy and paste. They made their expectations clear to the students to avoid plagiarism in their assignments in the beginning of the semester. Mr. Hari said he would do this because for him to give the expected expectations to students it was very important that they understood that plagiarism was not desirable in his class. Wilhoit (1994) mentioned it is important for students to be aware of their lecturers' expectation before submitting the assignments.

However, Ms. Kia and Ms. Anita also believes that plagiarism was not only about giving proper citations, but it is also about summarizing and paraphrasing sources. According to Ms. Kia, students needed to read journal articles, especially those that had good ratings so that students were able to learn how to write correctly and how advanced writers write. However, this thinking is contrary to Gullifer (2010) that argues students must get correct knowledge how to write in the real academic world. Gullifer (2010) states that it is paramount for lecturers to develop students' "sound skills in both research and writing, critically reading and comprehending appropriate sources, careful note-taking, paraphrasing, judicious use of quotations and giving credit to authors for their ideas and writing," (p. 464). At the same time, because students were in the middle of learning process, they were not required to provide a perfect writing. The reason for this is, as Ms. Anita mentioned, the desire of students to be able to produce perfect writing was the cause of many students plagiarized. This was the reason she always stressed in her class that "it [writing] doesn't have to be beautiful because Academic Writing isn't something that it's supposed to be beautiful."

\section{Students' Strategies to Avoid Plagiarism}

From interviews with students, the back translation method is what they often do to avoid plagiarism in their writing. Romi says,

"The first thing that I do is if the article is in English, I translate it into Indonesian, then I made it in my English. The article written in English is very academic writing (he meant the vocabulary is very advanced) so the vocabulary tends to be difficult. So the Indonesian version which I changed into my English version would be less detected as plagiarism.." 
Esa said that this was also done by many of her friends especially those who had low English proficiency.

"Sometimes there were lecturers who wanted the references [used on assignments] were not from Indonesia. They [her friends] would look for references using English. They translate it into Indonesian. So the process [of translating the texts] goes back and forth."

According to Stander (2018), back translation strategy is used when students have lack of comprehension of the text. His study revealed that when students understood the text, they were able to paraphrase and have their own voice in their academic written assignments.

\section{Students' Recommendation}

Of the 5 students interviewed, 3 admitted that they did not get enough knowledge about plagiarism, how to avoid plagiarism and the impact (punishment) if they did. They suggested that additional courses, particularly academic writing, should have been conducted

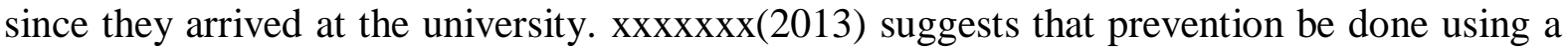
teaching approach (educational approach) rather than sanctions (punitive approach). Basically, all of the lecturers also agreed that plagiarism was something that had to be overcome by providing students with the appropriate knowledge of academic integrity. They recognized that a holistic approach was needed starting with the student' admission, matriculation programs, as well as portions of English lessons received by students.

\section{CONCLUSION}

This study was intended to find out how lecturers and students perceive plagiarism in students' writing, particularly in English. Besides this study also attempted to knows what the lecturers' strategies to inform students about plagiarism and the students' strategies to avoid plagiarism on their written assignments using English. The findings showed us that lecturers and students basically had the same perspective on plagiarism. They both agreed that plagiarism was something that should not be done in the education world. However, there were things that made students do plagiarism such as insufficient time to complete assignments, weak academic vocabulary coupled with lenient consequences for those who do plagiarism made them positive towards plagiarism. This implies that students will still practice plagiarism even though they are aware that it is prohibited in the academic world.. Therefore it is important for educational institutions to introduce to their students from the beginning about rules of writing in the academic world. In addition, it is also 
Risa.....

important to equip the students with appropriate English language skills, especially writing skills, so that they can avoid plagiarism in their writing.

\section{REFERENCES}

Adiningrum, T., \& Kutieleh, S. (2015). How different are we? Understanding and managing plagiarism between East and West. Journal of Academic Language \& Learning. Vol 5(2), A88-A98.

Agustina, R. \& Raharjo, P. (2017). Exploring plagiarism into perspectives of Indonesian academics and students. Journal of Education and Learning. Vol 11(3), 262-272.

Ajzen, I. (1991). The theory of planned behavior. Organizational Behavior and Human Decision Processes. Vol 50, 179-211.

Akbar, A. \& Picard, M. (2019) Strategies to help university students avoid plagiarism: a focus on translation as an intervention strategy. International Journal for Educational Integrity. Vol 15(7), 1-17.

Allport, G. W. (1935). Attitudes. In C. M. Murchison (Ed.), Handbook of Social Psychology. Winchester, MA: Clark University Press.

Cengage (2015, September 28). Students' Top Strategies for Avoiding Plagiarism [Blog spot]. Retrieved from https://blog.cengage.com/students-top-strategies-for-avoidingplagiarism/

Gullifer, J., \& Tyson, G. (2013). Who has read the policy on plagiarism? Unpacking students' understanding of plagiarism. Studies in Higher Education. Vol 39(7), 1202-1218.

Hacker, D. (1991). The Bedford handbook for writers (3rd ed.). Boston: Bedford Books of St. Martin's Press. 6.

Heigham, J., \& Croker, R. A. (2009). Qualitative research in applied linguistics: A practical introduction. New York: Palgrave Macmillan.

Howard, R.M. (1995). Plagiarisms, Authorships, and the Academic Death Penalty. College English. Vol 57(7), 788-806.

Howard, R. M. (1999). Standing in the shadow of giants. Stamford, CT: Ablex.

Keck, C. (2014). Copying, paraphrasing, and academic writing development: A reexamination of L1 and L2 summarization practices. Journal of Second Language Writing. Vol 25(Sep), 4-22.

Ostrom, T. M. (1969). The relationship between the affective, behavioral, and cognitive components of attitude. Journal of experimental social psychology. Vol 5(1), 12-30.

Pecorari, D. (2001). Plagiarism and international students: How the English-speaking university. In D. Belcher \& A. Hirvela (eds.), Linking literacies: Perspectives on L2 reading-writing connections (pp. 229-245). Ann Arbor, MI: University of Michigan 
Press.

Pecorari, D. (2013). Teaching to avoid plagiarism: How to promote good source use. Maidenhead, UK: Open University Press.

Power, L. (2009). University Students' Perceptions of Plagiarism. The Journal of Higher Education. Vol 80(6), 643-662.

Seftiawan, D. (2018, April 11). Akhirnya lampaui Singapura publikasi ilmiah Indonesia ke-2 ASEAN. Pikiran Rakyat. http://www.pikiranrakyat.com/pendidikan/2018/04/11/akhirnya- lampaui-singapurapublikasi-ilmiahindonesia-ke-2-asean-422670

Shi, L. (2006). Cultural backgrounds and textual appropriation. Language Awareness. Vol 15, 264-282.

Stander, M. (2018). Strategies to help university students avoid plagiarism: A focus on translation as an intervention strategy. Journal of Further and Higher Education, 114.

Strauss, A. \& Corbin, J., (1998). Basics of qualitative research: Grounded theory procedures and techniques (3rd ed.). Thousand Oaks, CA: Sage.

Sugiyono. (2016). Metode Penelitian Kuantitatif, Kualitatif dan $R \& D$. Bandung: PT Alfabet.

Villalva, K. E. (2006). Hidden literacies and inquiry approaches of bilingual high school writers. Written Communication.Vol 23(1), 91-129.

Wilhoit, S. (1994). Helping Students Avoid Plagiarism. College Teaching. Vol 42(4), 161164. 